\title{
Índice da Revista do Serviço Público - Ano XXII - 1959
}

\section{INDICE DE AUTORES}

A

Amaral, Carlos Gonçalo - Considerações em tôrno do Processo Administrativo - Ano XXII - Vol. 84 - N. 2 - agôsto de 1959 - pág. 213.

Amaral, Carlos Gonçalo - Colaboram neste número Curriculum vitae - Ano XXII - Vol. $84-$ N. $^{\circ} 2$ - agôsto de 1959 — pág. 251.

ArAgão, João Guilherme - Resultados e Perspectivas do Sistema de Cooperação Bilateral do Ponto IV - Ano XXII Vol. 84 - N. 1 - julho de 1959 pág. 34 .

ARAGÃo, João Guilherme - Curriculum vitae - Ano XXII - Vol. 83 - N. 3 pág. 111.

Araújo Cavalcanti - O Desenvolvimento planificado dos Municipios do Continente - Ano XXII - Vol. 82 - N. ${ }^{\circ}$ s 1,2 e 3 - janeiro, fevereiro e março de 1959 páig. 78.

Araújo Cavalcanti - Curriculum vitae Ano XXII - Vol. 82 - Ns. 1,2 e 3 - Janeiro, fevereiro e março de 1959 — pág. 217.

\section{B}

BonfIM, Alberto - A função judicante na esfera administrativa - Ano XXII Vol. 83 - N. ${ }^{\circ} 3$ - junho de $1959-$ pág. 352 .

Bonfim, Alberto - Curriculum vitae - Ano XXII - Vol. $83--\mathrm{N}^{\circ}{ }^{\circ} 3$ - junho de 1959 - pág. 393.

Baltazar, Alfredo (B) da Silveira - Comentário sôbre o Direito de Propriedade Notas - Ano XXII - Vol. 84 - N. 1 - julho de 1959 - pág. 98.

Baltazar, Alfredo (B) da Silveira - Curriculum vitae - Ano XXII - Vol. 83 N. 3 - julho de 1959 - pág. 111.

Bastos, Silva Geraldo - Estudos de educação secundária - Fatôres e conseqüêencias -
Expansão do Ensino Secundário Brasileiro - Administração especifica - Ano XXII - Vol. 83 - N. 3 - junho de 1959 pág. 261.

Bastos, Silva Geraldo - Curriculum vitae- Ano XXII - Vol. 83 - N. 3 junho de 1959 - pág. 393.

Botelho, Cleto de Paulo - Aspecto financeiro dos Municípios Brasileiros - Administração Municipal - Ano XXII Vol. 83 - N. 3 - junho de 1959 pág. 329.

Botel.ho, Cleto de Paula - Curriculum viae - Ano XXII - Vol. $83-$ N. $^{\circ} 3$ junho de 1959 - pág. 393.

\section{C}

Cardoso, Mary - O Serviço Civil e a formação da politica administrativa Tradução feita de um artigo de autoria de J. E. Hodgetts - Ano XXII - Vol. 82 - N. ${ }^{\circ}$ s 1,2 e 3 - janeiro, fereveiro e março de 1959 - pág. 11.

Cavalcante, Araújo - A Administração Pública e os Problemas da Automaçáo (Condições e perspectivas do emprêgo da Automação nos Serviços Público) - Ano XXII - Vol. 83 - N..$^{\circ}$ - abril de 1959.

Coaracy, Ada Maria - Reproduçáo de Documentos em Bibliotecas - Ano XXII - Vol. 82 - N.'s 1, 2 e 3 - janeiro, fevereiro e março de 1959 - pág. 49.

Coaracy, Ada Maria - Curriculum vitae Ano XXII - Vol. 83 - N. ${ }^{\circ}$ s 1, 2 e 3. - janeiro, fevereiro e março de 1959 pág. 217.

Costa, Vasco Ribeiro - A Rodovia Brasileira. Belém e o vale do Tocantins - Introdução. - Ano XXII - Vol. $84-\mathrm{N}^{\circ}{ }^{2}$ agôsto de 1959 - pág. 198.

Costa, Vasco Ribeiro - O Comércio Brasil Estados Unidos e a conquista de novos. mercados - Ano XXII - Vol. 84 N. ${ }^{\circ} 3$ - setembro de 1959 - pág. 259. 
Costa, Vasco Ribeiro - O Dominio aéreo do Estado e o espaço sideral - Ano XXII - Vol. 83 - N. ${ }^{\circ} 2$ - maio de 1959 pág. 197.

Costa, Vasco Ribeiro - Curriculum viae Ano XXII - Vol. 83 - N. ${ }^{\circ} 3$ - maio de 1959 - pág. 256.

Chagas Melo, Francisco - A criação do Banco Central - Secção de Finanças e Administração - Ano XXII - Vol. 83 - N. 2 - maio de 1959 - pág. 131.

Chagas Melo, Francisco - Curriculum vitae - Ano XXII - Vol. 83 - N. ${ }^{\circ} 2$ maio de 1959 - pág. 256.

Coutinho, Joaquim Henrique - Relatório do Ministro do Tribunal de Contas sôbre as teses da $2^{n}$ Comissão - Ano XXII Vol. 83 - N. ${ }^{\circ} 1$ - outubro de $1959-$ pág. 34.

Coutinho, Joaquim Henrique - Da necessidade do registro prévio (especialmente para a Revista do Serviço Público, pelo Ministro Joaquim Henrique Coutinho) Ano XXII - Vol. 85 - N. 1 outubro de 1959 - pág. 76.

\section{D}

Delorenzo Neto, Antônio - A Politica financeira da União em relação às entidades locais - O Regime de subvenções - Ano XXII - Vol. 85 - Ns. 2 e 3 - novembro e dezembro de 1959 pág. 154.

Delorenzo Neto, Antônio - Curriculum vitae - Ano XXIII - Vol. 85 - N. ${ }^{\circ}$ s 2 e 3 - novembro e dezembro de 1959 pág. 249.

Domingues Filho, Virgílio - Brasilia, a grande metrópole - Ano XXII Vol. 94 - N. 1 - julho de 1959 pág. 47.

Domingues Filho, Vir'gilio - Curriculum vitae - Ano XXII - Vol. $84-\mathrm{N} .^{\circ} 1$ — julho de 1959 - pág. 111.

\section{$\mathrm{F}$}

Ferrer Correia lima, Vicente - $\mathrm{A}$ área do novo Distrito Federal: condições de solo, clima e recursos naturais - Ano XXIII - Vol. 85 - N. ${ }^{\circ}$ s 2 e 3 - novembro e dezembro de 1959 - pág. 113.

FERRER Correia Lima, Vicente - Curriculum vitae - Ano XXIII - Vol. 85 - Ns. 2 e 3 - novembro e dezembro de 1959 pág. 249.

FAYAL DE LYRA, Charley - Odontologia e Serviços Públicos - Ano XXII -
Vol. 83 - N. 2 - maio de 1959 pág. 250.

FILGueiras, Dulcy Melgaço - População brasileira, uma análise da distribuição de seus grupos profissionais - Ano XXII Vol. 83 - N. 3 - junho de 1959 pág. 291.

Filgueiras, Dulcy Melgaço - Curriculum vitae -Ano XXII - Vol. 83 - N. ${ }^{\circ} 3$ — junho de 1959 - pág. 393.

FischlowitZ, Estanislau - Curriculum vitae - Ano XXII - Vol. 84 - N. 2 a Politica social e a Demógráfica - Ano XXII - Vol. 84 - N. ${ }^{\circ} 2$ - agôsto de 1959 - pág. 117.

Fischlowits, Estanislau - Curriculum vitae - Ano XXII - Vol. $84-$ N. 8 agôsto de 1959 - pág. 251.

FonseCA, Edson Nery - Alguns equivocos em tôrno da Classificação Decimal Universal - Ano XXII - Vol. 83 - N. 3 — junho de 1959 - pág. 321.

FonseCA, Edson Nery - Curriculum vitae Ano XXII - Vol. $83-\mathrm{N} .^{\circ} 3$ - junho de 1959 - pág. 393.

FREITAS, Rogério de - Discurso do Ministro Rogério de Freitas ao entregar ao Tribunal de Contas os anais do Congresso Ano XXII - Vol. 85 - N..$^{\circ}$ - outubro de 1959 - pák. 68.

\section{$\mathrm{H}$}

Hodgetts, J. E. - O Serviço Civil e a formação da Politica Administrativa (Tradução de Mary Cardoso) - Ano XXII - Vol. 82 - N.'s 1,2 e 3 - janeiro, fevereiro e março de 1959 - pág. 11.

Hugueney, Carlindo - Responsabilidade Civil dos Ministros de Estado (Direito e Jurisprudência - Doutrina) - Ano XXII Vol. 84 - N. ${ }^{\circ} 3$ - setembro de 1959 pág. 283.

Hugueney, Carlindo - Curriculum vitae Ano XXII - Vol. $84-$ N. $^{\circ} 3$ setembro de 1959 - pág. 418.

\section{J}

Joffily, Attilio - A floresta e as sêcas Ano XXII - Vol. 83 - N. ${ }^{\circ} 2$ - maio de 1959 - pág. 141. 
Joffily, Attilio - Curriculum vitae - (Attilio Joffily Pereira da Costa) - Ano XXII Vol. 83 - N. 2 - maio de 1959 pág. 256.

\section{K}

Kyle, Barbara - Problemas atuais da Documentação e sua importância para a Bibliografia das Ciências Sociais - (Tradução de Maria Amélia Pôrto Migueis) Ano XXII - Vol. 83 - N. ${ }^{\circ} 2$ - maio de 1959 - pág. 150.

\section{L}

LiRA, José Pereira - Discurso do Ministro José Pereira Lira na abertura do $3 .^{\circ}$ Congresso Internacional das Instituições Superiores de Contrôle das Finanças Públicas, na Câmara dos Deputados do Brasil, em 4 de maio de 1959 - Ano XXII - Vol. 85 - N. 1 - outubro de 1959 - pág. 20.

LIRA, José Pereira - Três Congressos Mundiais de Tribunais de Contas - Entrevista concedida à Revista do Serviço Público pelo então Presidente do Tribunal de Contas da União - Ano XXII - Vol. 85 - N. 1 - outubro de 1959 - pág. 5.

LIRA, José Pereira - O Tribunal de Contas e o Ministério Republicano de Serzedelo Correia - (Secção de História Administrativa do Brasil) - Ano XXIII Vol. $85-\mathrm{N} .{ }^{\circ}$ s 2 e 3 - novembro e dezembro de 1959 - pág. 102.

LIRA, José Pereira - Curriculum vitae Ano XXIII - Vol. 85 - N. ${ }^{\circ}$ s 2 e 3 novembro e dezembro de 1959 - pág. 249.

\section{M}

Maranhão, Jarbas - O Petróleo no Senado - Ano XXII - Vol. 83 - N. ${ }^{\circ} 3$ junho de 1959 - pág. 285.

MarignY, Elza Robillard - Restituição Ano XXII - Vol. 83 - N. 1 - abril de 1959 - pág. 47.

MarignY, Elza Robillard - Curriculum vitae - Ano XXII - Vol. 83 - N. ${ }^{\circ} 1$ abril de 1959 - pág. 125.

Melo, F. Chagas - O Projeto de Criação do Banco Central - Secção de Finanças e Administração da R.S.P. - Ano XXII Vol. $84-\mathrm{N} .^{\circ} 3$ - setembro de $1959-$ pág. 303.

Melo, F. Chagas - Curriculum vitae - Ano XXII - Vol. $84-\mathrm{N} \cdot{ }^{\circ} 3$ - setembro de 1959 - pág. 418.
Mıgueıs, Maria Amélia Pôrto - (Tradução de art. de Barbara Kyle) - Problemas atuais da Documentação e sua importância para a Bibliografia das Ciência Sociais Ano XXII - Vol. 83 - N. ${ }^{\circ} 2$ - maio de 1959 - pág. 150.

MigueIs, Maria Amélia Pôrto - Curriculum vitae - Ano XXII - Vol. 83 - N. 2 — maio de 1959 - pág. 256.

Monteiro Lopes, Tomás de Vilanova Fundamentos Históricos, Sociais e Econômicos da Construção de Brasília - Ano XXII - Vol. 82 - N. ${ }^{\circ}$ s 1,2 e 3 janeiro, fevereiro e março de 1959 pág. 6.

Monteiro Lopes, Tomás de Vilanova Curriculum vitae - Ano XXII - Vol. 85 - N.'s 2 e 3 - novembro e dezembro de 1959 - pág. 249.

Mosher, Frederick C. - «No principio era - verbo» - Comentário de um americano sôbre Ciências Administrativas - Traduzido por iniciativa do Instituto Brasileiro de Ciências Administrativas - Ano XXII - Vol. 83 - N. ${ }^{\circ} 3$ - junho de 1959 pág. 333.

\section{$\mathrm{N}$}

NEY DA Silva, João Luiz - Redação oficial do treinamento dos servidores - Ano XXII - Vol. 82 - N..$^{\circ}$ s 1,2 e 3 janeiro, fevereiro e março de 1959 pág. 42.

NeY DA SiLVA, João Luiz - Curriculum vitae - Ano XXII - Vol. 82 - N. $.^{\circ} 1,2 \mathrm{e}$ 3 - janeiro, fevereiro e março de 1959 — pág. 217.

\section{O}

OlrverRa, Yves Orlando Tito - Curriculum Interamericano de Direito Municipal Ano XXII - Vol. $84-$ N. $^{\circ} 1$ - julho de 1959 - pág. 68.

Oliveira, Yves Orlando Tito - Curriculum vitae - Ano XXII - Vol. $84-\mathrm{N}^{\circ} 1$ — julho de 1959 - pág. 111 .

\section{P}

Peçannha, Celso - Recuperação e Desenvolvimento dos municipios brasileiros Significado e importância da Operação Municipio - Ano XXII - Vol. 83 N. ${ }^{\circ} 2$ - maio de 1959 - pág. 189.

Peçanha, Celso - Projeto n. 3.702 de 1958 - Dispõe sôbre a Instituição do Plano de Recuperação e desenvolvimento dos 
municípios brasileiros e dá outras providências - Ano XXII - Vol. 84 N. 2 - agôsto de 1959 - pág. 190.

Peçanha, Celso - Curriculum vitae - Ano XXII - maio de 1959 - pág. 256.

PAUPÉRIO, A. Machado - O Regime jurídico da C.O.F.A.P. - Secção da R. S. P. «Direito e Jurisprudência - Doutrina» Ano XXII - Vol. 84 - N..$^{\circ} 1$ - julho de 1959 - pág. 53.

PAupÉRIO, A. Machado - Curriculum vitae - Ano XXII - julho de 1959 pág. 111.

PIMENTA, Joaquim - Responsabilidade civil do individuo e do Estado - Ano XXII - Vol. 83 - N. ${ }^{\circ} 3$ - junho de 1959 pág. 356.

Pimenta, Joaquim - «La Juridiction Administrative au Brésil» - (Secção da Rev. do Serv. Púb. - NOTAS - Nota biblio gráfica) - Ano XXII - Vol. 83 N. 2 - maio de 1959 - pág. 237.

Pimenta, Joaquim - Curriculum vitae Ano XXII - Vol. 83 - N. ${ }^{\circ} 3$ - junho de 1959 - pág. 393.

Pontes, Vieira - O Território de Fernando de Noronha e a segurança nacional Impacto e repercussões da Operação Arquipélago - Ano XXII - Vol. 82 - N. ${ }^{\circ}$ s 1,2 e 3 - janeiro, fevereiro e março de 1959 - pág. 119.

Poorterman, J. - Dos Diplomatas e de seu estatuto - Ano XXIII - Vol. 85 N. ${ }^{\circ}$ s 2 e 3 - novembro e dezembro de 1959 - pág. 120.

PugEt, Henry - O Novo direito da energia atômica - Caracteristicas gerais - organismos administrativos - Ano XXII Vol. 83 - N. ${ }^{\circ} 2$ - maio de 1959 pág. 171.

Puget, Henry - Curriculum vitae - Ano XXII - maio de 1959 - pág. 256.

Santos, Nelson Nascimento - A Matemática no Direito de propriedade da União janeiro, fevereiro março, maio, junho e agôsto de 1959 - Vols. 82, 83 e 84 N. ${ }^{\circ}$ s 1,2 e 3 - janeiro de 1959 pág. 169 - N.2 - maio de 1959 pág. $204-\mathrm{N}^{\circ} 3$ - junho de 1959 pág. 342 - N. ${ }^{\circ} 2$ - agôsto de 1959 pág. 221

Santos, Nelson Nascimento - Curriculum vitae - Ano XXII - Vol. 83 - maio de 1959 - pág. 256

SiLva, Fenelon - Nomenclatura e terminologia da Documentação - Administração Geral - Documentação - Ano XXII -
Vol. 83 - N. ${ }^{\circ} 2$ - maio de 1959 pág. 145.

Silva, Fenelon - Metodologia da Documentação - Administração Geral - Ano XXII - Vol. 84 - N. 1 - julho de 1959 - pág. 23.

Silva, Fenelon - Curriculum vitae - Ano XXII - maio de 1959 - Vol. 83 N. ${ }^{\circ} 2$ - pág. 256.

SILVA, Benedito - Introdução à Administração Pública - Administração Pública - Ano XXII - N. ${ }^{\circ}$ s 1,2 e 3 - Vol. 82 janeiro, fevereiro e março de 1959 pág. 27.

Silva, Benedito - Curriculum vitae janeiro, fevereiro e março de 1959 pág. 217.

Silva, Geraldo Bastos - Curriculum vitae Ver: Bastos, Silva Geraldo.

Silveira, Alfredo Balthazar - A Enfiteuse no Supremo Tribunal - Palestra - Ano XXII - Vol. 82 - N. ${ }^{\circ}$ s 1,2 e 3 janeiro, fevereiro e março de 1959 pág. 175.

Silveira, Alfredo Balthazar - Do Poder Judiciário - Ciência Politica e Administrativa - Ano XXII - Vol. 83 - N. 1 — abril de 1959 - pág. 6.

SILVEIRA, Alfredo Balthazar - Curriculum vitae - Ver: Balthazar Silveira.

Souto Maior - Projeto n. ${ }^{\circ}$ 4.656-58 Dispõe sôbre o "Convênio Interamericano de Cooperação Intermunicipal» autoriza a realização de estudos e projetos especiais relativos à Operação Pan-Americana; e dá outras providências - Ano XXIII Vol. 85 - N. ${ }^{\circ}$ s 2 e 3 - novembro e dezembro de 1959 - pág. 165.

\section{$\mathrm{T}$}

TÁcito, Caio - Delegação de Podêres a Instituições Autônomas - Instituto Brasileiro de Ciências Administrativas - Ano XXII - Vol. 84 - N. 2 - agôsto de 1959 - pág. 145.

TÁcrto, Caio - Curriculum vitae - Ano XXII - Vol. 84 - N. ${ }^{\circ} 2$ - agôsto de 1959 - pág. 251.

Torres, Marcilio Vaz - Apontamentos de Arquivística - Ano XXII - Vol. 84 N. ${ }^{\circ} 2$ - agôsto de 1959 - pág. 138.

Torres, Marcilio Vaz - Curriculum vitae Ano XXII - agôsto de 1959, pág. 251.

Tovar, Jair - Servidões Administrativas Direito e Jurisprudência - Doutrina Ano XXII - Vol. $84-\mathrm{N}^{\circ} 2$ - agôsto de 1959 - pág. 207. 
Tovar, Jair - Curriculum vitae - N. 2 agôsto de 1959 - pág. 251.

TRAvassos, Renato - Educação Popular Ano XXII - Vol. 84 - N. 2 - agôsto de 1959 - pág. 132.

Travassos, Renato - Curriculum vitae N. ${ }^{\circ} 2$ - agôsto de 1959 - pág. 251.

\section{V}

Vilanova, Tomás V. Monteiro Lopes e Vicente, Ferrer Correia Lima - A Companhia Urbanizadora da Nova Capital do Brasil: recursos, organização e funcionamento - Ano XXIII - Vol. 83 N. ${ }^{\circ} 2$ - maio de 1959 - pág. 136.

Vilanova, Tomás V. Monteiro Lopes Curriculum vitae - Ano XXIII - Vol. 85 - novembro e dezembro de 1959 pág. 249.

VIDO, Maria - Curriculum vitae - Ano XXIII - Vol. 83 - abril de 1959 pág. 125.

VIDo, Maria - Curriculum vitae - Ano XXIF - Vol. 83 - abril de 1959 pág. 125.

Vilanova, Tomás V. Monteiro Lopes D. João VI e a Administração Pública Brasileira - Ano XXII - Vol. 84 N. 1 - julho de 1959 - pág. 5.

Violich, Francis - Planejamento Regional na América Latina - Ano XXII - Vol. 84 - N. ${ }^{\circ} 2$ - Agôsto de 1959 - pág. 155.

Violich, Francis - Curriculum vitae Ano XXII - Vol. 84 - agôsto de 1959 - pág. 25.

VRAnCKen, Fernand - Discurso do Doutor Vrancken, Primeiro Presidente da Côrte de Contas da Bélgica, na sessão solene de inauguração do Congresso, na Câmara dos Deputados, em 4-5-59 - Ano XXII Vol. 85 - N. 1 - outubro de 1959 pág. 31 .

\section{W}

WAHRLICH, Beatriz M. de Souza - O Aumento de eficiência da Administração através da concessão de prêmios e incentivos ao Funcionário - Ano XXII Vol, 84 - N. ${ }^{\circ} 3$ - setembro de 1959 — pág. 309.

Wahrlich, Beatriz M. de Souza - Curriculum vitae - setembro de 1959 - pág. 418.

\section{INDICE DE ASSUNTOS}

A

Abandono de CARgo - Prescrição da pena Ano XXII - Vol. 83 - N. ${ }^{\circ} 1$ - abril de 1959 - pág. 89.

ACÓRDÃos - Ver pelo titulo respectivo de cada acórdão.

AcumulaçÃo de CARgos - Ano XXII N. ${ }^{\circ} 3$ - Vol. 84 - setembro de 1959 pág. 389.

Acumulação de Cargos - Competência da Comissão respectiva - Ano XXII Vol. 83 - N. 1 - abril de 1959 pág. 87.

Acumulação de Cargos - Art. 24 do Ato das Disposições Constitucionais Transitórias - Descabimento dos recurso - Ano XXII - Vol. 83 - N. ${ }^{\circ} 2$ - maio de 1959 - pág. 221.

A Administração Pública e os Ploblemas DA Automação - Condições e Perspectivas do emprêgo da Automação nos Serviços Públicos - Ano XXII Vol. 83 - N. 1 - abril de 1959 pákg. 15.

ÅGı: parcela integrante do preço efetivo do produto de mercadoria - Lei n. ${ }^{\circ} 2.145$, de 1953 - Recurso extraordinário em mandado de segurança n. 29.579 D.F. - Ano XXII - N. 3 - Vol. 84 — setembro de 1959 - pág. 394.

ÁGıos - Os ágios ações de sociedade anônima, estão sujeitas ao impôsto de renda, como verdadeiro lucro que são - Ano XXII - N. ${ }^{\circ} 2$ - Vol. 84 - agôsto de 1959 pág. 241.

Agravo DE Instrumento - Ação de desapropriação - Nega-se provimento ao interposto com o fim de reformar a decisão que fixa a quantia a depositar e defere pedido de imissão em ação de desapropriação - (Tribunal Federal de Recursos) Ano XXII - Vol. 83 - N. 2 - maio de 1959 - pág. 233.

ANIVERSÁRIO DO D.A.S.P. - Saudação do Diretor-Geral do D.A.S.P. em seu 21. aniversário, Dr. João Guilherme de Aragão - Ano XXII - N. ${ }^{\circ} 3$ - Vol. 84 setembro de 1959 - pág. 409.

ApOSENTADORIa - Aposentadoria com prévia promoção ao cargo de Juiz de Direito com vencimentos de Desembargador - Consultor-Geral da República - Ano XII - Vol. 83 - N. ${ }^{\circ} 2$ - maio de 1959 pág. 214 . 
ApOSENTADORIA - Agravo em petição em mandado de segurança n. ${ }^{\circ} 4.087$ Impossibilidade de acumulação de proventos pagos pelo Tesouro Nacional com pensấo a cargo de instituição de previdência social - Ano XXII - N. ${ }^{\circ}$ s 2 e 3 Vol. 85 - novembro e dezembro de 1959 — pág. 238.

APLICAÇÃO DA LEI N. $2.752-56$ - Dualidade de aposentadoria - Consultor-Geral da República - Ano XXII - Vol. 82 N."s 1,2 e 3 - janeiro, fevereiro e março de 1959 - pág. 181.

APOSENTADORIA — Dualidade de aposentadoria - Parecer do Consultor-Geral da República - Ano XXII - Vol. 82 - N. ${ }^{\circ}$ s 1 . 2 e 3 - janeiro, fevereiro e março de 1959 - pág. 181.

APOSENTADORIA - É regulada conforme a lei vigente ao tempo em que solicitada Acórdão do Supremo Tribunal Federal, Recurso extraordinário de n. ${ }^{\circ} 23.229-$ D.F. - Ano XXII - Vol. 82 - N. ${ }^{\circ}$ s 1, 2 e 3 - janeiro, fevereiro e março de 1959 - pág. 193.

Arquivística - Apontamentos de Arquivistica - Autoria do Prof. Marcilio Vaz Torres - Ano XXII - N. 2 - Vol. 84 agôsto de 1959 - pág. 138.

APOSENTADORIA - Aposentadoria com mais de 35 anos de serviço dos quais mais de 10 em cargos de comissão - Parecer do Consultor-Geral da República - Ano XXII - N. ${ }^{\circ} 3$ - Vol. 83 - junho de 1959 - pág. 361.

AposentADORIA - Aposentadoria com mais de 35 anos de serviço - Interpretação da alinea $b$ e $\S 10^{\circ}$ do art. 180 do Estat. dos Funcionários Públicos - Ano XXII N. 3 - Vol. 83 - junho de 1959 pág. 366.

ApOSENTADORIa - Aposentadoria dupla, por dois cargos - Tempo de serviço - Como se conta - Segurança negada - Acórdão do S.T.F. - Ano XXII - N. ${ }^{\circ} 3$ Vol. 84 - setembro de 1959 - pág. 392.

APOSENTADORIA - Aposentadoria de servidor ocupante de cargo isolado em comissão - Direito de opção - Inteligência adequada das normas contidas nos arts. 180 e 184 do Estat. dos Func. Púb. - Acórdão do S.T.F. - Ano XXII - Vol. 83 N. ${ }^{\circ} 1$ - abril de 1959 - pág. 92.

APOSENTADORIA - Aposentadoria com vencimentos integrais por moléstia grave que atingiu servidor que, mesmo assim, completou, em serviço 70 anos de idade Parecer do Consultor-Geral da República
- Ano XXII - N. 1 - Vol. $84-$ julho de 1959 - pág. 80.

Área do Novo Distrito Federal - Condições de solo, clima e recursos naturais Artigo de Vicente Ferrer Correia Lima e Tomás de Vilanova M. Lopes sôbre a nova capital (Brasília) - Ano XXIII Vol. 85 - N. ${ }^{\circ}$ s 2 e 3 - novembro e dezembro de 1959 - pág. 113.

ASPECTO FINANCEIRO DOS MunicípIOS BRASILEIROS - Art. de Cleto de Paula Botelho - Ano XXII - N. 3 - Vol. 83 junho de 1959 - pág. 329.

Atividades do Serviço de Documentação Do D.A.S.P. - Reportagem publicada no Jornal do Comércio de 20-9-59 - Ano XXIII - Vol. 85 - Ns. 2 e 3 novembro e dezembro de 1959 - pág. 244.

Ato Administrativo - Revogabilidade Lei n. ${ }^{\circ} 200$ - Acórdão do Trib. Fed. de Rec. - Ano XXII - Vol. 83 - N. ${ }^{\circ}$ — abril de 1959 - pág. 101.

Atos Administrativos - Pode a autoridade revogá-los quando contrários à lei - Atos ilegais não geram direitos subjetivos Acórdão do S.T.F. - Ano XXIII Vol. 85 - N. ${ }^{\circ}$ s 2 e 3 - novembro e dezembro de 1959 - pág. 224.

Ато Administrativo $-\mathrm{O}$ ato administrativo estreme de vicios e nulidades, e do qual resultem direitos individuais, não pode ser revogado pela própria Administração Ano XXIII - Vol. 85 - Ns. 2 e 3 novembro e dezembro de 1959 - pág. 229.

Administração Federai - A atuação do D.A.S.P. nas grandes etapas da Administração Federal Editoral - Ano XXII Vol. 84 - N. ${ }^{\circ} 2$ - agôsto de 1959 pág. 115.

AutomaçÃo - A Administração Pública e os problemas da Automação - Oposições e perspectivas do emprêgo da Automação nos Serviços Públicos - Ano XXII Vol. 83 - N. ${ }^{\circ} 1$ - abril de $1959-$ pág. 15.

A AtuAÇÃo do SeCRETÁRIO - Executivo do II Congresso Ibero-Americano de Municipios - NOTAS - Ano XXII - Vol. 84 - N. 1 - julho de 1959 - pág. 108.

\section{B}

Banco Central - A criação do Banco Central - Artigo de F. Chagas Melo Ano XXII - Vol. $83-\mathrm{N} .^{\circ} 2-$ maio de 1959 - pág. 131. 
BRASiLIA - Realidade iminente - Editorial Ano XXII - Vol. $83-\mathrm{N} .^{\circ} 2$ - maio de 1959 - pág. 129.

Brasília - Fundamentos históricos, sociais e econốmicos da construção de Brasilia Ns. 1,2 e 3 - janeiro, fevereiro e março de 1959 - pág. 6.

A Área do Novo Distrito Federal - Condições de solo, clima e recursos naturais Ano XXIII - Vol. 85 - Ns. 2 e 3 novembro e dezembro de 1959 - página 113.

Biblioteca Moderna e a Documentação Art. da Bibliotecária Maria Vido - Ano XXII - Vol. 83 - N..$^{\circ} 1$ - abril de 1959 - pág. 43.

Brasília - A grande metrópole - Art. de Virgilio Domingos Filho - Ano XXII Vol. 84 - N. 1 - julho de 1959 pág. 47.

Brasília - Em Brasilia o III Congresso Ibere-Americano de municipios - A Companhia Urbanizadora da nova capital do Brasil: recursos, organização e funcionamento - Art. de Tomás Vilanova $\mathrm{M}$. Lopes e Vicente Ferrer C. Lima - Ano XXII - Vol. 83 - N. 2 - maio de $1959^{-}$- pág. 136.

\section{C}

CADUCIDADE - Direito à reversão, com apoio na Lei n. ${ }^{\circ} 171$, de 1947 - Aposentadoria com fundamento no art. 197 - Cons. Jur. D.A.S.P. - Ano XXII - N. ${ }^{\circ} 1$ Vol. 84 - julho de 1959 - pág. 83.

Cargo Público - Acesso só permitido a brasileiros natos ou naturalizados - $\mathrm{A}$ Lei n..$^{\circ} 2.284$ de 1954, não incide sôbre os servidores estrangeiros, em face do atrigo 184 da Constituição Federal - Ano XXII - N. 3 - Vol. 83 - junho de 1959 pág. 265.

Centenário - O centenário da "Origem das Espécies》 - Comentário - Ano XXII Vol, 84 - N." 3 - setembro de 1959 pág. 414.

Classificação Decimal Universal - Alguns equivocos em tôrno da C.D.U. - Art. de Edson Nery da Fonseca - Ano XXII Vol. 83 - N. ${ }^{\circ} 3$ - junho de 1959 pág. 321.

Cobrança - De contribuições de previdência - Ilegitima sua cobrança a profissionais que prestam serviços à firma, mas sem vinculo de emprêgo - Trib. Fed. Rec. Ano XXII - N: 3 - Vol. 83 - junho de 1959 - pág. 376 .
Comentário - Sôbre o Direito de Propriedade - Ligeiras considerações acêrca do art. do Prof. Joaquim Pimenta - Ano. XXII - Vol. 84 - N. 1 - julho de 1959 - pág. 98.

Comércio - O comércio Brasil-Estados Unidos e a conquista de novos mercados Art. de Vasco Ribeiro da Costa - Ano XXII - Vol. 84 - N..$^{\circ}$ - setembro de 1959 - pág. 253.

Comissão de Impôsto Sindical - Pessoal da Secretaria da C.I.S. e C.T.O.S. - Natureza juridica da relação de emprêgo Processo n. ${ }^{\circ}$ 3.636-59 - Ano XXIII Vol. 85 - N.'s 2 e 3 - novembro e dezembro de 1959 - pág. 216.

CApITAL do BRAsIL - A companhia urbanizadora da nova capital do Brasil: recursos, organização e funcionamento - Art. de Vicente Ferrer C. Lima e Tomás de Vilanova M. Lopes - Ano XXII Vol. 83 - N. 2 - maio de 1959 pầg. 136.

Companhia Urbanizadora - Da nova capital do Brasil (Brasilia): recurso, organização e funcionamento - Ano XXII - Vol. 83 - N. 2 - maio de 1959 - pág. 136.

CompetênCia da Justiça Comum - Competência da justiça comum para dirimir conflitos entre as Prefeituras municipais e os seus empregados na primeira instância - Tribunal Superior do Trabalho Ano XXII - Vol. 85 - Ns. 2 e 3 nom vembro e dezembro - pág. 241.

COMPETENCIA DA JUSTIÇA Especializada Para julgar reclamações formuladas por empregados da Rêde Federal S. A. (Estrada de Ferro Leopoldina) - Trib. Reg. do Trab. - Ano XXII - N. 3 Vol. 83 - junho de 1959 - pág. 382.

Corretor de Fundos Públicos - Não é cargo público no conceito do Estatuto dos: Funcionários Públicos Civis - Consultor Juridico do DASP. - Ano XXII Vol. 82 - N.'s 1, 2 e 3 - janeiro, fevereiro e março de 1959 - pág. 187.

CONCLUSÕES DAS COMISSÕES - Comissões do $3 .^{\circ}$ Congresso Internacional das Instituições Superiores de Contrôle das Finanças Públicas, em 9 de maio de 1959, do Tribunal de Contas da União - $1^{4}$ quéstão A E B; $2^{3} ; 3^{4}$ e $4^{4}$ - Ano XXII - Vol. 85 - N. 1 - outubro de 1959 - pág. 61 .

Concurso - Para provimento de cargos. isolados de Professor de Ensino Técnico, padrão «O» do Quadro Permanente da 
P.D.F. - Direito à nomeação - Mandado de segurança n. ${ }^{\circ} 1.205-\mathrm{S}$.T.F. - Ano XXII - Vol. 82 - N. ${ }^{\circ}$ s 1, 2 e 3 - janeiro, fevereiro e março de 1959 — pág. 195.

Candidato Aprovado - Em concurso para Professor de Ensino Técnico do Curso Básico e Curso Técnico, padrão $\varangle \mathrm{O}$ do Q.P. da P.D.F. - janeiro, fevereiro e março de 1959 - pág. 195.

Concurso de Monografias - Aberto pela Revista do Serviço Público com o propósito de dar maior incentivo ao estudo dos problemas de Adminitsração Pública Brasileira - Portaria n." 281, de 1959 do D.F. do D.A.S.P. - Ano XXII Vol. 83 - N. 2 - maio de 1959 pág. 253.

Congressos DE T. C. - Três congressos de Tribunais de Contas - Entrevista concedida à Revista do Serviço Público pelo Ministro Pereira Lira, Presidente do 3. ${ }^{\circ}$ congresso e também. Presidente do Tribunal de Contas da União - Ano XXII - Vol. 85 - N. ${ }^{\circ} 1$ - outubro de 1959 - pág. 5.

Congressos - Ecos do II Congresso IberoAmericano de Municipios - Ainda sôbre - congresso realizado no periodo de 19 de maio de 1959, em Lisboa - Ano XXII - N. ${ }^{\circ}$ - Vol. 84 - agôsto de 1959 pág. 248.

Congressos - Em Brasilia o III Congresso Ibero-Americano de Municipios - Ano XXII - $\mathrm{N}^{\circ} 3$ - Vol. 83 - junho de 1959 - pág. 388.

Congresso Internacional - De Ciências Administrativas - I. B. C. A. - Ano XXII - N. ${ }^{\circ} 1$ - Vol. 84 - julho de 1959 - pág. 31.

CONSIDERAÇÕES EM CONSIDERAÇÕES EM TÔRNO do Processo Administrativo - Ano XXII - N.o 2 - Voi. 84 - julho de 1959 - pág. 213.

Contrato - Contratos celebrados pela E. F. Santos a Jundiai de arrendamento de terrenos, aquisição de materiais e para construção de fábrica de carros e vagões de aço inoxidável - Ano XXII - N. ${ }^{\circ} 3$ - Vol. 83 - junho de 1959 - pág. 362.

Correlação - Correlação entre a politica social $e$ a demográfica - Ano XXII - N. ${ }^{\circ} 2$ —Vol. 84 - agôsto de 1959 - pág. 117.

Concurso - Para provimento de cargos isolados de Prof. de Ensino Técnico (Curso Básico e Curso Técnico) padrão (O) do Q.P. da P.D.F. - Direito à nomeação - Ano XXII - N.'s 1, 2 e 3 - Vol. 82 - janeiro, feverziro e março. de 1959 - pág. 195.

\section{D}

DE Direito dE Transferência para O. S.P.F. - De ex-empregado da emprêsa «A Manhã», incorporada ao patrimônio nacional - Parecer do Cons. Jur. do. D.A.S.P. - Ano XXII - Vol. 84 N. 1 - julho de 1959 - pág. 83.

D.A.S.P. - Missão reformadora do D.A.S.P. - Editoral - Ano XXII - Vol. 84 - N. ${ }^{\circ} 3$ - setembro de 1959 - página 255 .

D.A.S.P. - A atuação do D.A.S.P. nas grandes etapas da Administração Federal - Editorial - Ano XXII - Vol. 84 N." 2 - agôsto de 1959 - pág. 115.

O D.A.S.P. - No II Congresso IberoAmericano de Municipios - Notas Ano XXII - Vol. 83 - N. 3 - junho. de 1959 - pág. 383.

Data - Data até a qual deve ser pago o vencimento ou a remuneração do servidor falecido - Idem, no que concerne ao funcionário aposentado, exonerado ou demitido - Parecer do Cons. Jur. do. D.A.S.P. - Ano XXII - Vol. 84 N. 2 - agôsto de 1959 - pág. 240.

Declaração Tardia - Não isenta do pagamento de impôsto, mas exclui aplicação da multa - Acórdão do T. F. R. - Ano. XXII - Vol. 84 - N.o 2 - agôsto de 1959 - pág. 245.

Delegação de PoDÊRes a Instituição AutôNomas - Art. de Caio Tácito - Ano. XXII - Vol. 84 - N. ${ }^{\circ} 2$ - agôsto de 1959 - pág. 145.

Desenvolvimento - O desenvolvimento planificado dos Municipios do continente Uma contribuição objetiva à «Operação. Pan-Americana - Ano XXII - Vol. 82 - N. ${ }^{\circ}$ s 1,2 e 3 - janeiro, fevereiro e março de 1959 - pág. 78 .

Despazimento - Da nomeação do Catedrático de Tisiologia da Faculdade de Crurgia e Medicina do Pará - Parecer do. Cons. Ger. da Rep. - Ano XXII Vol. 83 - N. 3 - junho de 1959 pág. 361.

Diferença de Vencimentos - Diferença deque trata o parágrafo único do art. $4 .^{\circ} \mathrm{da}$ Lei n. $^{\circ} 488$, de 1948 - A Lei n. ${ }^{\circ} 2.745$. de 1956 não revogou aquela norma Cons. Jur. do D.A.S.P. - Ano XXIII Vol. 85 - 1959 - pág. 222. 
Diplomatas - Dos Diplomatas e de seu Estatuto - Art. de J. Poorterman traduzido sob os auspícios do Inst. Bras, de Ciências Adm. - Ano XXIII - Vol. 85 - N. ${ }^{\circ}$ s 2 e 3 - novembro e dezembro de 1959 - pág. 120.

DIREITO ADQUIRIDO - O Direito adquirido do servidor estadual, hoje Juiz do Trabalho, em ver contado o seu tempo de serviço em dôbro, ou em condições de concorrência, não pode ser oposto à União e a esta obrigar, o que é contra texto expresso da lei federal.

Direito de Candidato - Que passou em concurso devidamente homológado a ser aproveitado no prazo da lei - Apelação civel n. ${ }^{\circ} 39.709$ - Ano XXII - Vol. 82 - N.'s 1,2 e 3 - janeiro, fevereiro e março de 1959 - pág. 202.

Direito de PROPRIĘDADE - Comentário sôbre o direito de propriedade - Ligeiras considerações acêrca do art. do Prof. Joaquim Pimenta - Notas - Ano XXII Vol. 84 - N..$^{\circ}$ - julho de 1959 pág. 98.

Discurso - Discurso do Ministro José Pereira Lira na abertura do $3 .^{\circ}$ Congresso Internacional das Instituições Superiores de Contrôle das Finanças Públicas, na Câmara dos Deputados do Brasil, em 4 de maio de 1959 - Ano XXII - Vol. 85 N. ${ }^{\circ} 1$ - outubro d 1959 - pág. 20.

Discurso - Do Dr. Fernand Vrancken, Primeiro Presidente da Côrte de Contas da Bélgica, na sessão solene de inauguração do Congresso, na Câmara dos Deputados, em 4 de maio de 1959 - Ano XXII - Vol. 85 - N. ${ }^{\circ} 1$ - outubro de 1959 - pá'g. 31.

Discurso Do P. R. - Discurso do Excelentissimo Senhor Presidente da República, Dr. Juscelino Kubitschek de Oliveira, encerrando a sessão solene de abertura do 3. ${ }^{\circ}$ Congresso Internacional das Instituições de Contrôle das Finanças Públicas - Ano XXII - Vol. 85 - N. 1 outubro de 1959 - pág. 27.

Discurso do Ministro Rogério de Freitas Ao entregar os Anais (com 7 cartas) ao Tribunal de Contas do Congresso Ano XXII - Vol. 85 - N. ${ }^{\circ} 1$ - outubro de 1959 - pág. 68 .

Discurso do Ministro Pereira Lira - Presidente do $3 .^{\circ}$ Congresso e Presidente do Trib. de Contas do Brasil; encerrando o 3. Congresso Internacional das Instituições Superiores de Contrôle das Finanças
Públicas, em 9 de maio de 1959, no Auditório do Palácio da Fazenda - Ano XXII - Vol. 85 - N. ${ }^{\circ} 1$ - outubro de 1959 - pág. 61.

Discurso do Ministro Pereira Lira - $\mathrm{Na}$ sessão solene realizada pelo Tribunal de Contas em homenagem a Portugal, com que foi recebida a Delegação do T. C., de Portuigal, em 12 de maio de 1959 Ano XXII - Vol. 85 - N. ${ }^{\circ} 1$ - outubro de 1959 - pág. 93.

Discurso do Pres. Rep. - Visita do Pres. da Rep. ao D.A.S.P. no dia do $210^{\circ}$ aniversário de sua criação - Ano XXII Vol. 84 - N.o 3 - setembro de 1959 pág. 404.

Discurso do Senador Públio de Mello Representante do Maranhão, no Senado, em homenagem à memória do Dr. Urbano Santos da Costa Araújo, pelo $10^{\circ}$ centenário de seu nascimento - Notas - Ano XXII - Vol. $84-$ N. 1 - julho de 1959 - pág. 103.

Documentação - Atividades do Serviço de Documentação do D.A.S.P. - Reportagem publicada no jornal do Comércio de 20-9-59, por Maria Therezinha C. L. Oliveira - Notas - Ano XXIII Vol. 85 - N. ${ }^{\circ}$ s 2 e 3 - novembro e dezembro de 1959 - pág. 244.

DocumentaÇão - Biblioteca moderna e a Documentação - Art. de Maria Vido Ano XXII - Vol. 83 - N.o 1 - abril de 1959 - pág. 43.

Domínio AÉreo - O Dominio aéreo do Estado e o espaço sideral - Art. de Vasco Ribeiro da Costa - Ano XXII Vol. 83 - N." 2 - maio de 1959 pág. 197.

DomínIO DA UNIÃo - A remissão do fôro de terras do Dominio da União só se justifica a juizo do Pres. da Rep. e por proposta do Ministério da Fazenda - Ano XXII - Vol. 83 - N. 2 - maio de 1959 pág. 217.

DocumENTAÇ̃̃o - Nomenclatura e terminologia da Documentação - Artigo de autoria de Fenelon Silva - Ano XXII - Vol. 83 - N. 2 - maio de 1959 - pálg. 145.

\section{E}

Edtorial - Ver pelo título inicial, respectivamente.

Educação Secundária - Estudos de Educação Secundária - Fatôres e consequiências - Expansão do ensino secundário brasi- 
leiro - Art. de Geraldo Bastos Silva Ano XXII - Vol. 83 - N. ${ }^{\circ} 3$ - julho de 1959 - pág. 261.

Educação Popular - Artigo de Renato Travassos - Ano XXII - Vol. 84 N. ${ }^{\circ} 2$ - agôsto de 1959 - pág. 132.

EFICIÊNCIA DA AdMINISTRAÇÃo - $\mathrm{O}$ aumento de eficiência da Administração através da concessão de prêmios e incentivos ao funcionário - Art. de Beatriz M. de Souza Wahrlich a ser apresentado ao $\mathrm{X}$ Congresso Internacional de Ciências Administrativas - Ano XXII - Vol. 84 - N.o 3 - setembro de 1959 - pág. 309.

EMPRÊSAS DA UNIĨ̃ - As emprêsas da União não estão isentas do pagamento das custas - Embargos rejeitados - Proc. T.S.T. 2.538-57-E - Ano XXII - Vol. 84 N. ${ }^{\circ} 2$ - agôsto de 1959 - pág. 247.

EMPRÉSAs - As emprêsas que possuem quadro organizado em carreira não se aplicam as disposições de eqüivalência funcional e salarial prescritas no art. 461 , devendo as promoções obedecer ao critério alternado de antíguidade e merecimento - Ano XXII - Vol. 83 - N. 2 - maio de 1959 - pág. 236.

EMPRÉSTIMO - Entre particular e instituto de previdência social, visando à aquisição de apartamentos para residência - Indeferimento da pretensão - Ano XXII Vol. 84 - N. ${ }^{\circ} 1$ - julho de 1959 pág. 92.

ENERgia Atômica - O Novo direito de energia atômica - Caracteristicas gerais - Organismos administrativos - I.B.C.A. - Ano XXII - Vol. 83 - N. 2 maio de 1959 - pág. 171.

Enfiteuse - A enfiteuse no Supremo Tribunal - Palestra do Prof. Alfredo Balthazar da Silveira - Ano XXII - Vol. 82 N. ${ }^{\circ}$ s. 1,2 e 3 - janeiro, fevereiro e março de 1959 - pág. 175.

EQÜIDADE - Não se confunde com direito liquido e certo - Assim, não possibilita a concessão do mandado de segurança Trib. Reg. do Trab. - Ano XXII Vol. 83 - N.o 1 - abril de 1959 pág. 110.

EQUIPARAÇÃo - Equiparação de operários do Arsenal de Marinha ao da Imprensa Nacional - Seu reconhecimento à vista de preceitos legais - Ano XXIII Vol. 85 - Ns. 2 e 3 - novembro e dezembro de 1959 - pág. 224.
EQUIPARAÇÃo - A equiparação salarial incide sôbre a existência de funções idênticas, não sendo possivel deferi-la em relação o atividades diversas em carreiras desiguais - Acórdão do Trib. Reg. do Trab. Ano XXII - Vol. 82 - N. ${ }^{\circ}$ s. 1,2 e 3 - janeiro, fevereiro e março de 1959 pág. 198.

ESTABILIDADE - Recurso extraordinário, seu desprovimento, quando inexistentes os seus alegados pressupostos - Acórdão do S.T.F. - Ano XXII - Vol. 84 N. ${ }^{\circ} 1$ - julho de 1959 - pág. 90.

Estudos de EducaçÃo SECundáRIa - Fatôres e conseqüências - Expansão do Ensino Secundário Brasileiro - Art. de Geraldo Bastos Silva - Ano XXII - Vol. 83 N. 3 - junho de 1959 - pág. 261.

E.T.U.B. - Pessoal admitido no E.T.U.B. à conta da antiga Verba 4 - Aplicação do disposto no art. $1^{\circ}$ da Lei $\mathrm{n}^{\circ} 3.483$, de 1958 - Ano XXII - Vol. 84 N. ${ }^{\circ} 2$ - agôsto de 1959 - pág. 238.

EXERCÍcIO DE MAGISTÉRIO - Em estabelecimento particulares, por parte dos militares da ativa - Parecer do Cons. Geral da Rep. - Ano XXII - Vol. 84 - N.o 2 — agôsto de 1959 — pág. 236.

EXIGÊnCIA de Prévio Concurso - Para todos os cargos de provimento efetivo das autarquias e entidades paraestatais - Lei n. ${ }^{\circ} 1.584$ de 1959 - Cons. Jur. do D.A.S.P. - Ano XXIII - Vol. 85 N. ${ }^{\circ}$ s. 2 e 3 - novembro e dezembro de 1959 - pág. 219.

Exoneração A Pedido - Art. 75, n. $^{\circ}$ I, do Estatuto dos Funcionários - Proposta de regulamentação - Parecer do Cons. Jur. do D.A.S.P. - Ano XXII - Vol. 84 N. 3 - setembro de 1959 - pág. 390.

Ecos do II Congresso Ibero-Americano DE Municípios - Nota de «O Mundo Português» de 28-6-59, sôbre êste congresso, realizado em Lisboa, no período de 19 de maio de 1959 - Ano XXII - Vol. 84 N. ${ }^{\circ} 2$ - agôsto de 1959 - pág. 248.

\section{F}

Fazenda Nacional de Sta. Cruz - Pedido de remição de aforamento - Parecer do Cons. Jur. do D.A.S.P. - Ano XXIII - Vol. 85 - Ns. 2 e 3 - novembro e dezembro de 1959 - pág. 215.

A Floresta e as Sêcas - Artigo de Atilio Joffily - Ano XXII - Vol. 83 - N. 2 — maio de 1959 - pág. 141. 
FÔRO DE TERRAS DO DOMínIO DA UNIÃo Sendo a conclusão do Ministério da Fazenda contrária ao resgate, não há como deferi-la - Ano XXII - Vol. 83 - N. ${ }^{\circ} 2$ - maio de 1959 - pág. 217.

A Função Judicante - Na esfera administrativa - Artigo de Alberto Bonfim Ano XXII - Vol. 83 - N. 3 - junho de 1959 - pág. 352.

FunCionáRIO - O aumento de eficiência da Administração através da concessão de prêmios e incentivos ao funcionário I.B.C.A. - Ano XXII - Vol. 84 N. 3 - setembro de 1959 - pág. 309.

Funcionário Demitido - A bem do serviço público - A persistência da nota desabona ex-servidor para o exercício de função pública, impossibilitando-lhe a readmissão - Parecer do Cons. Jur. do D.A.S.P. Ans XXIII - Vol. 85 - Ns. 2 e 3 novembro e dezambro de 1959 - página n. ${ }^{\circ} 218$.

Funcionário Interino - Inscrito em concurso; pode ser exonerado independentemente do processo administrativo Acórdão do S.T.F. - Ano XXII Vol. 83 - N. 1 - abril de 1959 pág. 96.

Funcionário que Abandona o Cargo Injustificadamente, ausentando-se do pais sem autorização de seus superiores Processo T.R.T. n. ${ }^{\circ}$ 44-EP-57 - Ano XXII.

Funcionário Público - Equiparação de cargos - Nenhuma ofensa à lei federal - Sup. Trib. Fed. - Ano XXII Vol. 82 - N.os. 1, 2 e 3 - janeiro, fevereiro e março de 1959 - pág. 192.

Funcionário Público - Se a decisão recorrida se apiar em lei municipal, isso não abriria ensejo ao recurso extraordinário, que visa garantir a eficácia da lei federal - Ano XXII - Vol. 84 - N. ${ }^{\circ} 1$ julho de 1959 - pág. 89.

Fundamentos Históricals de Brasília Sociais e econômicos da construção de Brasilia - Ano XXII - Vol. 82 N. ${ }^{\circ}$ s. 1,2 e 3 - janeiro, fevereiro e março de 1959 - pág. 6.

\section{G}

GratificaçÃo Pro-labore Facto - Apresenta serviço já prestado e a gratificação prolabore faciendo, também chamada gratifi- cação de função, é estatuida para serviços extraordinários ou não, que forem prestados - Acórdão do Trib. de Jus. do D.F. - Ano XXII - Vol. $83-\mathrm{N}^{\circ}{ }^{1}$ abril de 1959 - pág. 112.

GRATIFICAÇÃo - Pela execução de trabalho de natureza especial, com risco de vida ou saúde - Parecer do Cons. Jur. do D.A.S.P. - Ano XXII - Vol. 83 N. 1 - abril de 1959 - pág. 86.

\section{I}

Instituto Brasileiro de ClêNCIAS AdminisTRATIVAS - Ver titulo de cada artigo.

INCOMPETÊNCIA DA JUSTIÇA dO TRABalho Para apreciar e decidir os litigios entre a Rêde Ferroviária Federal S. A. e seus empregados - Acórdão - Ano XXII Vol. 83 - N. ${ }^{\circ} 3$ - junho de 1959 pág. 379.

IMPÔSTO DE Consumo - Sôbre mercadorias importadas - Inclusão dos ágios cambiais, para efeito do cálculo do impôsto Acördão - Ano XXII - Vol. 84 N. ${ }^{\circ} 3$ - setembro de 1959 - pág. 396.

Impôsto Estadual - Não é devido nenhum impôsto estadual sôbre o simples contrato. de promessa de compra - Ano XXII Vol. 84 - N. 3 - setembro de 1959 pág. 396.

IMPÔSTO DE RENDA - Sua não incidência sôbre prêmio de seguro dotal - Tribunal Fed. de Rec. - Ano XXII - Vol. 84 N. 3 - setembro de 1959 - pág. 398.

IMPÔSTO DE VENDAS E CONSIGNaçÕES - Incide sôbre bonificação cambial - Acórdão do S.T.F. - Ano XXII - Vol. 84 N. 2 - agôsto de 1959 - pág. 241.

IMPROCEDÊNCIA — Da argüição de caducidade da autorização para pesquisa de minérios na Serra de Yacadígo, em Corumbá, Estado de Mato Grosso - Cons. Jur. do D.A.S.P. - Ano XXII - Vol. 84 N. ${ }^{\circ} 1$ - julho de 1959 - pág. 85.

INDICE DA R.S.P. - Indice do ano XXI 1958, da Revista do Serviço Público Ano XXII - Vol. 82 - N. ${ }^{\circ}$ s. 1,2 e 3 janeiro, fevereiro e março de 1959 pág. 206.

INFRAÇÃO - Infração do disposto no art. 194. n. ${ }^{\circ}$. VI e VII do E.F.P. - Autoridade competente para a aplicação da penalidade - Parecer do Cons. Jur. do D.A.S.P. Ano XXII - Vol. 83 - N..$^{\circ}$ - junho de 1959 - pág. 368. 
InTRODUÇ̃̃̃ A AdMINISTRAÇÃo PúBLICA Artigo de Benedito Silva - Ano XXII - Vol. 82 - N.os. 1.2 e 3 - janeiro, fevereiro e março de 1959 - pág. 27.

I.A.P.E.T.C. - Fôro - Pode o I.A.P.E.T.C ser acionado em qualquer capital de Estado-membro - Acórdão do T.F.R. - Ano XXII - Vol. 83 - N. ${ }^{\circ} 2$ maio de 1959 - pág. 234.

\section{J}

D. JoÃo VI E A AdMinistração Pública Brasileira - Artigo de Tomás de Vilanova M. Lopes - Ano XXII - Vol. 84 — N. ${ }^{\circ} 1$ - julho de 1959 - pág. 5.

La JURIDISTION Administrative Au BrÉsiL Artigo de Joaquim Pimenta - Notas Ano XXII - Vol. $83-\mathrm{N} .^{\circ} 2$ - maio de 1959 - pág. 237.

\section{L}

LEı 200 - Funcionário do Dominio da União em serviço nas Delegacias não têm direito ao benefício do art. $10^{\circ}$ dessa Lei Mandado de ségurança denegado Acórdão do S.T.F. - Ano XXII Vol. 83 - N. ${ }^{\circ} 1$ - abril de 1959 pág. 98.

LICENÇA PARA TRATO DE INTERÊSSES PARTICULARES - As disposições do Código Civil, quanto à fixação do domicilio da familia pelo marido, são de ordem pública Parecer do C. J. do D.A.S.P. - Ano XXII - Vol. 84 - N.o 2 - agôsto de 1959 - pág. 239.

Listas dE Delegados - Listas de delegados assessôres, observadores e assistentes Tribunal de Contas da União - Ano XXII - Vol. 85 - N. ${ }^{\circ} 1$ - outubro de 1959 - pág. 81.

\section{M}

Mandado de Segurança - Direitos patrimoniais - Inidoneidade do mandado - Não é meio processual idôneo para a asseguração de direitos patrimoniais - Ano XXIII - Vol. 85 - N.os. 2 e 3 - novembro e dezembro de 1959 - pág. 234.

Manual dos Prefeitos E Vereadores Projeto n. ${ }^{\circ}$ 4.294-58 - Autoriza o Cons. Nac. de Pesq. a organizar e publicar, por intermédio do Instituto Brasileiro de Bibliografia e Documentação, o Manual dos Prefeitos e Vereadores; estabelece as bases da particpação do D.A.S.P. e dá A.B.M. na realização conjunta dêsse empreendimento e dá outras providências - Ano XXII - Vol. 83 - N. 1 abril de 1959 - pág. 75.
A Matemática no Direito de Propriedade da UnIÃo - Artígo de Nelson Nascimento Santos - Parte 1 - Vol. 82 - N. ${ }^{\circ}$ s. 1 . 2 e 3 - janeiro, fevereiro e março de 1959 - pág. 169 - Parte II - Vol. 83 N.o 2 - maio de 1959 - pág. 204 Parte III - Vol. $83-\mathrm{N} .^{\circ} 3$ - junho de 1959 - pág. 342 - Parte IV Vol. 84 - N. ${ }^{\circ} 2$ - julho de 1959 pág. 221.

Mensalistas DA UnNão - Também dos Estados, D.F., Territórios e Municipios, a êles se estendem os diversos preceitos da «Consolidação das Leis do Trabalho Lei n..$^{\circ} 1.890$, de 1953 - Acórdão do S.T.F. - Ano XXII - Vol. 84 N.o 1 - julho de 1959 - pág. 87.

MESA REDONDA DE LIEEGE - Relatório sôbre a mesa redonda de Liège, do Instituto Internacional de Ciências Administrativas - Elaborado pelo I.B.C.A., Seção Nacional Brasileira do Instituto Internacional de Ciências Administrativas - Ano XXII - Vol. 82 - N. ${ }^{\circ}$ s. 1,2 e 3 janeiro, fevereiro e março de 1959 pág. 69.

Metodologia da DocumentaçÃo - Artigo de Fenelon Silva - Ano XXII - Vol. 84 - N. ${ }^{\circ} 1$ - julho de 1959 - pág. 23.

Missáo Reformadora do D.A.S.P. Editorial da Rev, do Ser. Púb. - Ano XXII - Vol. 84 - N. 3 - pág. 255.

Mulher CASADa - Embora funcionária de uma autarquia, precisa autorização do marido para obrigar-se cambialmente Acórdão do S.T.F. - Ano XXII Vol. 83 - N.o 3 - junho de $1959-$ pálg. 374 .

Municipalismo Atuante - Editorial da Rev. do Serv. Púb. - Ano XXII - Vol. 83 N. 3 - junho de 1959 - pág. 259.

Municipıos - A atuação do Secretário-Executivo do II Congresso Ibero-Americano de municipios - Ano XXII - Vol. 84 N. ${ }^{\circ} 1$ - julho de 1959 - pág. 108 Ecos do II Congresso Ibero-Americano de municipios - Ano XXII - Vol. 84 N. ${ }^{\circ} 2$ - agôsto de 1959 - pág. 248. II Congresso Ibero-Americano de municipios - Ano XXII - Vol. 83 - N.o 3 junho de 1959 - pág. 388 - O Desenvolvimento planificado dos municipios do continente - Uma contribuição objetiva à «Operação Pan-americana - Artigo de Araújo Cavalcanti - Ano XXII Vol. 82 - N. ${ }^{\circ}$ s. 1,2 e 3 - janeiro, fevereiro e março de 1959 - pág. 78 . 
$\mathrm{N}$

Da Necessidade do Registro Prévio Especialmente para a Rev. do Serv. Púb., pelo Ministro Joaquim Henrique Coutinho do Tribunal de Contas da União Ano XXII - Vol. 85 - N. ${ }^{\circ} 1$ - outubro de 1959 - pág. 76.

Nomenclatura e Terminologia da DoCUMENTAÇÃo - Artigo de Fenelon Silva - Ano XXII - Vol. 83 - N. ${ }^{\circ} 2$ maio de 1959 - pág. 145.

Normas Destinadas ao Preparo e Execução de Reformas Administrativas - Tradução patrocinada pelo I. B. C. A. Ano XXII - Vol. 83 - N.o 1 - abril de 1959 - pág. 52.

O Novo Direito de Energia Atômica Caracteristicas gerais - Organismos administrativos - Traduzido sob os auspicios do I.B.C.A. - Ano XXII - Vol. 83 N. 2 - maio de 1959 - pág. 171.

\section{O}

OpERAÇÃO PAN-AMERICANA - O Desenvolvimento Planificado dos Municipios do Continente - Uma contribuição objetiva à "Operação Pan-Americana - Art. de Araújo Cavalcanti - Ano XXII Vol. 82 - N.'s. 1,2 e 3 - janeirc fevereiro e março de 1959 - pág. 78.

Odontologia e Serviços Públicos - Artigo de Charley Fayal de Lyra - Notas Ano XXII - Vol. 83 - N. ${ }^{\circ} 2$ - maio de 1959 - pág. 250.

OPERAÇÃo Arquipélago - O Território de Fernando de Noronha e a segurança nacional - Impacto e repercussões da «Operação Arquipélago» - Projeto do Deputado Pontes Vieira - Ano XXII Vol. 82 - N.os. 1, 2 e 3 - janeiro, fevereiro e março de 1959 - pág. 119.

OPERAÇão MUNIĆ́PIO - Recuperação e Desenvolvimento dos municipios brasileiros Projeto $\mathrm{n} .^{\circ} 3.702$, de 1958 do Deputado Federal Celso Peçanha - Ano XXII Vol. 83 - N. 2 - maio de 1959 pág. 189.

\section{$\mathrm{P}$}

Pedido de EfetivaçÃo - Cargo de Promotor com fundamento no artigo $90 \mathrm{n}^{\circ} 1.341$, de 30-1-50, Lei orgânica do Ministério Público da União - Parecer do Cons. Ger. da Rep. - Ano XXII - Vol. 82 N. ${ }^{\text {ss. }} 1,2$ e 3 - janeiro, fevereiro e março de 1959 - pág. 181.
Pessoal Admitido - No E.T.U.B., à conta da antiga Verba 4, Aplicação do disposto no art. $1 .^{\circ}$ da Lei n. 3.483 de 1958 Parecer do Cons. Jur. do D.A.S.P. Ano XXII - Vol. 84 - N.2 - agôsto de 1959 - pág. 238.

Pessoal de Obras - Da E.F.C.B. é beneficiário da lei de acidentes do trabalho Em processo de acidente do trabalho não há condenação em honorários de advogado. - Acórdão do T.F.R. - Ano XXII Vol. 84 - N. 2 - agôsto de 1959 pág. 244.

Pessoal de Obras da União - Sujeito à lei de acidentes no trabalho - Nos casos de acidente de trabalho não há margem para recurso de ofício - Acórdão do T.F.R. - Ano XXII - Vol. 84 - N.0 1 julho de 1959 - pág. 94 .

Petrobrás - Isenção de impostos - Extensão à taxa de previdência social - Distinção entre taxas e impostos pròpriamente ditos. - Conceito doutrinário e conceito legal - Cons. Jur. D.A.S.P. - Ano XXII - Vol. 82 - Ns. 1,2 e 3 - janeiro. fevereiro e março de 1959 - pág. 188.

O Petróleo no Senado - Senador Jarbas Maranhão - Ano XXII - Vol. 83 N. 3 - junho de 1959 - pág. 285.

Planejamento Regional na América LaTINA - Art. de Francis Violich - Ano XXII - Vol. 84 - N..$^{\circ} 2$ - agôsto de 1959 - pág. 155.

Do Poder Judiciário - Art. de Alfredo. Balthazar da Silveira - Ano XXII Vol. 83 - N.o 1 - abril de 1959 pág. 6.

A Política Financeira da UUNião em Relação Às EnTIDAdes Locais - O Regime de subvenções - Artigo de Antônio Delorenzo Neto - Ano XXIII - Vol. 85 Ns. 2 e 3 - novembro e dezembro de 1959 - pág. 154.

População Brasileira, uMa ANálise dA DistribuiçÃo DE SEUS GRUPOS ProficioNaIs - Artigo de Dulcy Melgaço Filgueiras - Ano XXII - Vol. 83 - N. 3 - junho de 1959 - pág. 291.

PRESCRIÇÃo - Da falta disciplinar - Interpretação do art. $213, n{ }^{\circ}$ II, alinea $b$, do Estatuto dos Funcionários - Quando, por fôrça de motivos supervenientes, ocorridos após a instauração do processo administrativo, o servidor passar à inatividade, o prazo de que trata o dispositivo acima citado será contado a partir da data em que se efetivou essa alteração funcional Ano XXII - Vol. 84 - N. 3 setembro de 1959 - pág. 388. 
PRESENÇA DO ItAMARATI - Editorial - Ano XXII - Vol. 83 - N..$^{\circ}$ - abril de 1959 - pág. 3.

Presença do Tribunal de Contas da União - Eidtorial - Ano XXII - Vol. 85 $\mathrm{N}^{\circ} 1$ - outubro de 1959 - pág. 3.

O PREsidente DA República visitou O D.A.S.P. - Notas - Visita do Pres. da Rep. por ocasião do $210^{\circ}$ aniversário do órgão - Ano XXII - Vol. 84 N.o 3 - setembro de 1959 - pág. 401.

A Prestação de Serviços Eventuais Mediante recibo, năo caracteriza relação de emprếgo, como se infere, a contrár:o sensu, d odisposto no art. $30^{\circ}$ da Constituição das Leis do Trabalho - Ano XXII - Vol. 84 - N. ${ }^{\circ} 1$ - julho de 1959 pág. 83.

«NO PRINCípIO ERA O VERBO» - Comentário de um americano sôbre Ciências Administrativa I. B. C. A. - Ano XXII Vol. 83 - N. 3 - junho de 1959 pág. 333.

PRINCIPAis RealizaçõES DO D.A.S.P. - Em 1956, 1957 e 1958 - Notas - Ano XXII - Vol. 83 - N. 1 - abril de 1959 pág. 114.

Problemas Atuais da Documentação e sua IMPORTÂNCIA PARA A BIBLIOGRAFIA DAS ClêNCIAS SociaIS - Art. de Barbara Kyle, tradução de Maria Amélia Pôrto Migueis - Ano XXII - Vol. 83 - N.o 2 maio de 1959 - pág. 150.

PROCESSO Administrativo - Inteligência do art. 200 do E.F. - Parecer do Cons. Jur. do D.A.S.P. - Ano XXIII Vol. 85 - Ns. 2 e 3 - novembro e dezembro de 1959 - pág. 221.

Procurador Judicial das Autarquias Para procurar e requerer em Juizo, deve estar regularmente inscrito na Ordem dos Advogados do Brasil - Acórdão do T.F.R. - Ano XXII - Vol. 83 N. 1 - abril de 1959 - pág. 100.

PRoJETo - De criação do Banco Central Artigo de F. Chalgas Melo - Ano XXII - Vol. 84 - N. ${ }^{\circ} 3$ - setembro de 1959 - pág. 303.

PROJETO N. ${ }^{\circ}$ 3.702, DE 1958 - Dispõe sôbre a instituição do Plano de Recuperação e desenvolvimento dos Municipios Brasileiros - Operação Municipio - Deputado Celso Peçanha - Ano XXII - Vol. 84 - N.0 2 - agôsto de 1959 - pág. 190.

Projeto N. ${ }^{\circ} 4 \cdot 227-58$ - Da Câmara dos Deputados - Institui o concurso \&Teixeira de Freitas» a ser realizado pelo I.B.G.E.. com a participação do D.A.S.P... da A.B.M. e do M.E.C. - Ano XXII Vol. 84 - N. ${ }^{\circ} 3$ - setembro de 1959 pág. 322.

Projeto N. ${ }^{\circ} 4.656-58$ - Dispõe sôbre o Convênio Interamericano de Cooperação Intermunicipal»; autoriza a realização de estudos e projetos especiais relativos à Operação Pan-americana, e dá outras providências - Ano XXII - Vol. 85 Ns. 2 e 3 - novembro e dezembro pág. 165.

Proposta de Dispensa de Funcionário Que reconsiderou seu pedido - Parecer do Cons. Ger. da Rep. - Ano XXII Vol. 84 - N. ${ }^{\circ} 2$ - agôsto de 1959 pág. 236.

Proposta de Promoção - De oficiais do Exército, em ressarcimento de preterição - Ano XXII - Vol. 83 - N. ${ }^{\circ} 2$ maio de 1959 - pág. 212.

PRÊmIo - Para ser deduzido da renda, o prêmio de seguro de vida há de ter sido efetivamente pago - Acórdão do S.T.F. - Ano XXII - Vol. $84-$ N. $^{\circ} 3$ setembro de 1959 - pág. 397.

PROFESSOR DE ENSINO TÉCNICO - Candidato aprovado em concurso para provimento de cargos isolados de Prof. de Ens. Téc. (Curso Básico e Curso Técnico), padrão «O» do Q.P. da P.D.F. - Direito à nomeação - Ácórdão do S.T.F. - Ano XXII - Vol. 82 - N.os. 1,2 e 3 janeiro, fevereiro e março de 1959 pág. 195.

PROVA DE REQUISIÇÃo DE FUNCIONÁRIO A fim de ter exercício em outro setor da administração pública, deve ser feita de modo inequívoco - Apelação civel do T.J.D.F. - Ano XXII - Vol. 82 N.'s. 1,2 e 3 - janeiro, fevereiro e março de 1959 - pág. 201.

Provimento de Funções e Cargos isolados. DAS AutARQuIAS - Parecer do Consultor Geral da República - Ano XXII Vol. 82 - N. ${ }^{\circ}$ s 1,2 e 3 - janeiro, fevereiro e março de 1959 - pág. 183.

Publicações Recebidas - Ano XXII Vol. 83 - N. ${ }^{\circ} 1$ - abril de 1959 pág. 123 - Ano XXII - Vol. 83 N. 3 - junho de 1959 - pág. 390 Ano XXII - Vol. 84 - N. 1 - julho de 1959 - pág. 109 - Ano XXII - Vol. 84 - N.o 2 - agôsto de 1959 - pág. 250 - Ano XXII - Vol. 84 - N. ${ }^{\circ}$ setembro de 1959 - pág. 416 - Ano. XXIII - Vol. 85 - Ns. 2 e 3 - novembro e dezembro de 1959 - pág. 247. 
R

Recurso ExtraordinÁRIO - Estabilidade, seu desprovimento, quando inexistentes os seus alegados pressuposto - Acórdão do S.T.F. - Ano XXII - Vol. 84 N. ${ }^{\circ} 1$ - julho de 1959 - pág. 90.

RECURSO ExtraordinÁR:o - N.` 34.490, D.F. Recurso extraordinário, seu descabimento - Ano XXII - Vol. 83 - N.0 2 maio de 1959 - pág. 220.

RECURSO EXTRAORDINÁkY - Conhecimento por comprovado o dissidio jurisprudencial As autarquias são obrigadas ao pagamento dos impostos estaduais - S.T.F.

Ano XXIII - Vol. 85 - Ns. 2 e 3 novembro e dezembro de 1959 - pág. 226.

Recurso Extraordinário - N. 38.188-D.F. - O recurso de oficio não cabe às autarquias - Acórdão do S.T.F. Ano XXIII - Vol. 85 - Ns. 2 e 3 novembro e dezembro de 1959 - pág. 227.

Recuperação e Desenvolvimento dos MunıĆ́PIOS BRASILEIROS - Significado e importância da Operação Municipio - Projeto n. $3.702-58$, do Dep. Celso Peçanha Ano XXII - Vol. 83 - N. ${ }^{\circ} 2$ - maio de 1959 - pág. 189.

Redação Oficial no Treinamento dos SerVIDORES - Artigo de João Luiz Ney Ano XXII - Vol. 82 - N. ${ }^{\circ}$ s 1,2 e 3 janeiro, fevereiro e março de 1959 pálg. 42.

REFLEXÕES SÔBRE O PARLAMENTO - Editorial - Ano XXII - Vol. 82 - N. ${ }^{\circ}$ s 1,2 e 3 - janeiro, fevereiro e março de 1959 pág. 3.

Reformas Administrativas - Normas destinadas ao preparo e execução de reformas administrativas - Tradução patrocinada pelo I.B.C.A. - Ano XXII - Vol. 83 - N. 1 - abril de 1959 - pág. 52.

O Regime JuRídico DA C.O.F.A.P. - Artigo de A. Machado Paupério - Ano XXII Vol. 84 - N. 1 - julho de 1959 pág. 53.

Regime Jurídico - Do pessoal das Estradas de ferro Leopoldina e Santos a Jundiaí - Revogação do Dec.-lei n. ${ }^{\circ}$ 8.249-45 Parecer do Cons. Jur. do D.A.S.P. Ano XXII - Vol. 82 - Ns. 1,2 e 3 - janeiro, fevereiro e março de 1959 pág. 185.

Registro PRÉvio - Da necessidade do registro prévio (pelo sr. Ministro Henrique Coutinho, especialmente para a Revista do Serviço Público - Ano XXII - Vol. 85 - N.o 1 - outubro de 1959 - pág. 76.
A REgulAmentaÇÃo DAs LeIS INCOMPLETAS Editorial - Ano XXII - Vol. 84 N. ${ }^{\circ} 1$ - julho de 1959 - pág. 3.

Relatório sôbre a Mesa REDONDA de LIÈGe - Do Instituto Internacional de Ciências Administrativas - I. B. C. A. Ano XXII - Vol. 82 - N. ${ }^{\circ}$ s 1. 2 e 3 janeiro, fevereiro e março de 1959 pág. 69.

Relatório do Ministro Joaquim Henrique Coutinho - Do T. C. do Brasil sôbre as teses da $2^{7}$ Comissão apresentadas perante a Secretaria do III Congresso Internacional das Instituições Superiores de Contrôle das Finanças Públicas - Ano XXII - Vol. 85 - N. ${ }^{\circ} 1$ - outubro de 1959 - pálg. 34.

REMunERAÇÃO DOS PROFESSÔReS - Insubsistência do parágrafo único do art. 323 da Consolidação das Leis do Trabalho e das Portarias baixadas pelo M.E.C., com fundamento naquele dispositivo - Ano XXII - Vol. 83 - N.o 1 - abril de 1959 - pág. 104.

REPORTAGEM SÔBRE O D.A.S.P. - Realizada pelo Journal Français du Brésil, n. ${ }^{\circ} 160$, 8 eme année, ler Février, 1959 - Ano XXII - Vol. 83 - N. 2 - maio de 1959 - pág. 244.

Reprodução de Documentos em Bibliotecas - Artigo de Ada Maria Coaracy - Ano XXII - Vol. 82 - N.'s 1. 2 e 3 janeiro, fevereiro e março de 1959 pág. 49.

REQUISIÇÃo DE FunCIONÁRIO - Para servir de jurado num Júri popular: como deve ser atendida - Acórdão do T.R.T. - Ano XXII - Vol. $84-$ N.o 3 - setembro de 1959 - pág. 400.

Responsabilidade CiviL do Indrvíduo E DO Estado - Artigo de Joaquim Pimenta Ano XXII - Vol. 83 - N..$^{\circ}$ - junho de 1959 - pág. 356.

Responsabilidade Civil dos Ministros DE Estado - Artigo de Carlindo Hugueney - Ano XXII - Vol. 84 - N. ${ }^{\circ} 3$ setembro de 1959 - pág. 283.

Restabelecimenty - Da Portaria n. 36. do Departamento de Administração do M.T.I.C., relativa à efetivação de extranumerários tarefeiros admitidos antes da Lei n. 02.284 de 1954 - Ano XXII - Vol. 83 - N. ${ }^{\circ} 2$ - maio de 1959 - pág. 212.

RestrTuIÇ̃̃o - Artigo de Elza Robillard de Marigny - Ano XXII - Vol. 83 N. 1 - Abril de 1959 - pág. 47 . 
Resultados e Perspectivas do Sistema de Cooperação Bilateral do Ponto iv Artigo de J. Guilherme de Aragão Ano XXII - Vol. $84-$ N. ${ }^{\circ} 1$ - julho de 1959 - pág. 34.

Revista do Serviço Público - Concurso de monografias aberto com o propósito de dar ma:or incentivo ao estudo dos problemas de Administração Pública Brasileira, pela Portaria n. ${ }^{2} 281$, de 1959 , do Diretor Geral do D.A.S.P. - Ano XXII Vol. 83 - N. 2 - maio de 1959 pág. 253.

Rodovia Brasília-Belém e o Vale do ToCANTins - Artigo de Vasco Ribeiro da Costa - Ano XXII - Vol. 84 N. 2 - agôsto de 1959 - pág. 198.

\section{S}

SAlários de Extranumerários - Fixados acima do limite estabelecido pela Lei n. $^{\circ} 2.284$, de 1954 - Parecer do Cons. Ger. da Repúb. - Ano XXII - Vol. 84 - N.o 1 - julho de 1959 - pág. 80.

SALÁRIO-FAMílIA - Interpretação do art. 138 n. ${ }^{\circ}$ IV, e respectivo parágrafo único do Estat. dos Func. - Parecer do Cons. Jur. do D.A.S.P. - Ano XXII Vol. 83 - N..$^{\circ}$ - junho de $1959-$ pág. 370.

Seminário Interamericano de Diretto MuniCIPAL - Primeiro seminário - Art. de Yves de Oliveira - Ano XXII - Vol. 84 - N. ${ }^{\circ} 1$ - julho de 1959 - pág. 68.

O Serviço Civil e a Formação Política Administrativa - Artigo de J. E. Hodgetts, em tradução de Mary Cardoso Ano XXII - Vol. 82 - N.os 1,2 e 3 - janeiro, fevereiro e março de 1959 pág. 11.

Serviço de Navegação da Baf́a do Prata O empregado do S.N.B.P. não goza das vantagens do funcionalismo público em geral, estando, pois, sujeito ao regime da Lei n. ${ }^{\circ} 1.890$ - Acórdão do T. F. R. - Ano XXII - Vol. 84 - N. 2 a'gôsto de 1959 - pág. 244.

Servidor Público - Vinculado a emprêsa ferroviária - Cômputo do tempo de serviço nos têrmos da legislação em vigor para os func. púb. - Acórdão do S.T.F. - Ano XXII - Vol. 83 - N. 3 junho de 1959 - pág. 371.

Servidốs Administrativas - Artigo de autoria de Jair Tovar - Ano XXII Vol. 84 - N.o 2 - agôsto de 1959 pág. 207.
Sistema de Remuneração Composta - De ordenado e cotas para certos funcionários, não podia deixar de compreender os que, na mesma repartição exercessem o mesmo serviço - Acórdão do S.T.F. - Ano $\mathrm{XXII}$ - Vol. 83 - N. 3 - junho de 1959 - pág. 373.

SuBstiruição - Normas que regulam o Instituto - Quanto ocorre prolongamento desta após a vacância do cargo - Parecer do Cons. Jur. do D.A.S.P. - Ano XXII - Vol. 83 - N. 3 - Junho de 1959 - pág. 367.

\section{$\mathrm{T}$}

TAREFEIROS - A tarefeiros não sujeitos a horário normal de 8 horas, nem ao comparecimento diário, não assiste direito à implementação do salário-mínimo - Acórdão do T.R.T. - Ano XXII - Vol. 84 — N. 1 - julho de 1959 - pág. 96.

Temário do Congresso - III Congresso Internacional das Instituições Superiores de Contrôle das Finanças Públicas, realizado em 9 de maio de 1959, no auditório do Palácio da Fazenda, presidido pelo Tribunal de Contas da União - Ano XXII Vol. 85 - N. ${ }^{\circ} 1$ - outubro de 1959 pág. 63.

TERRAS DO DOMiNIO DA UNIÃO - A remição do fôro de terras do Dom. da União só se justifica a juizo do P.R. e por proposta do Min. Faz. realizadas as demais condições do art. 103 e seus $\S 2 .^{\circ}$ do D.L. n. 9.760 , de 1946 - Fazenda Nacional de Sta. Cruz - Ano XXIII Vol. 85 - N. ${ }^{\circ}$ s 2 e 3 - novembro e dezembro de 1959 - pág. 215.

Território de Fernando de Noronha e A Segurança Nacional - Impacto e repercussões da «Operação Arquipélago Projeto de lei n. ${ }^{\circ}$ 3.743-58, do Dep. Federal Pontes Vieira - Ano XXII Vol. 82 - N. ${ }^{\circ}$ s 1, 2 e 3 - janeiro, fevereiro e março de 1959 - pág. 119.

TransferênCIa DE SERVidor - Dispõe sôbre transferência de servidor da Estrada de Ferro Leopoldina para o Conselho Nacional do Petróleo e sôbre direitos dos empregados das Estradas de Ferro encampadas pela Uniấo - Parecer do Cons. Ger, da Rep. - Ano XXII - Vol. 84 N.o 1 - julho de 1959 - pág. 81.

Treinamento de Pessoal - Editorial da R.S.P. - Ano XXII - Vol. 85 Ns. 2 e 3 - novembro e dezembro pág. 99. 
TRIBunal de Contas da UnNião - Editorial: Presença do Tribunal de Contas da União - Ano XXII - Vol. 85 - N. ${ }^{\circ} 1$ outubro de 1959 - pág. 3.

O Tribunal de Contas e o Ministério Republicano de Serzedelo Correia Pelo Ministro José Pereira Lira - Ano XXIII - Vol. 85 - Ns. 2 e 3 - novembro e dezembro de 1959 - pág. 102.

Tribunal de Contas - Discurso do Ministro José Pereira Lira na abertura do $3 .^{\circ}$ Congresso Intern. das Instituições Super. de Contrôle das Fin. Púb., na Câmara dos Dep. do Brasil, em maio de 1959 - Ano XXII - Vol. 85 - N. ${ }^{\circ} 1$ - outubro de 1959 - pág. 20.

Terceiro Congresso InTERnACIONAal DAs InSTITUIÇỖES SUPERIORES DE CONTRÔLE DAS FinanÇAS - Realizado na Câmara dos Deputados do Brasil, em 4-5-59 - Assuntos referentes ao Congresso, ver Revista do Serviço Público de outubro de 1959.
V

Vencimentos dos Procuradores da República $\mathrm{E}$ de Procuradores das autarquias se desvincularam dos atribuidos aos Curadores, Promotores substitutos da Justiça do Distrito Federal - Parecer do Cons. Jurd. do D.A.S.P. - Ano XXII - Vol. 83 N. 2 - maio de 1959 - pág. 215.

Verba 4 - Pessoal admitido no E.T.U.B., à conta da antiga Verba 4; aplicação do disposto no art. $10^{\circ}$ da Lei n. $0^{\circ} 3.483$, de 1958 - Parecer do C.J. do D.A.S.P. - Ano XXII - Vol. 84 - N. 2 agôsto de 1959 - p;g. 238.

Visita de Associación Uruguaya de AdmiNisTRACión PúBlica - Notas da R.S.P. - Ano XXII - Vol. 83 - N. 2 maio de 1959 - pág. 255.

Visita do PRES, DA REP. AO D.A.S.P. Discurso do Presidente da República ao D.A.S.P., por ocasião da passagem do $21^{\circ}$ aniversário dêste órgão - Ano XXII - Vol. 84 - N. 3 - setembro de 1959 - pág. 404. 